\title{
Expression of the X-CGD Gene during Induced Differentiation of Myeloid Leukemia Cell Line HL-60
}

\author{
KATHLEEN A. BARKER, ${ }^{1}+$ STUART H. ORKIN ${ }^{2}$ AND PETER E. NEWBURGER ${ }^{1 *}$ \\ Departments of Pediatrics and Molecular Genetics/Microbiology, University of Massachusetts Medical School, \\ Worcester, Massachusetts $01655,^{1}$ and Division of Hematology-Oncology and Howard Hughes Medical Institute, \\ Children's Hospital, Department of Pediatrics, Harvard Medical School, Boston, Massachusetts 02115
}

Received 29 January 1988/Accepted 28 March 1988

\begin{abstract}
The expression of the X-CGD gene, which encodes the heavy-chain subunit of the phagocyte cytochrome $b$, was studied during induced myeloid differentiation of HL-60 cells. Incubation of the cells with a combined regimen of retinoic acid and dimethyl formamide resulted in granulocytic morphological differentiation and acquisition of nitroblue tetrazolium reduction, a measure of superoxide generation. During the 5-day course of induced differentiation, the levels of X-CGD mRNA transcripts rose 13-fold, with a 2-fold increase detectable within $3 \mathrm{~h}$ of exposure to retinoic acid. Relative transcription rates for the X-CGD gene, determined by nuclear runofi, increased two- to eightfold after 24 to $72 \mathrm{~h}$ of induced differentiation. However, the greater change in X-CGD mRNA levels than that in transcription rates implies the involvement of posttranscriptional regulation as well. Fractionation by centrifugal elutriation into phases of the cell cycle showed expression of X-CGD transcripts predominantly in $G_{1}$ cells before induction and in all phases of the cell cycle $24 \mathrm{~h}$ after induction. Thus the rapid increase in X-CGD expression in induced cells reflects the acquisition of functional competence and not the concomitant cessation of proliferation or shift in cell cycle distribution.
\end{abstract}

Phagocytic cells such as granulocytes and macrophages produce superoxide, peroxide, and other reactive oxygen intermediates with microbicidal, tumoricidal, and inflammatory effects $(1,28)$. The central reaction in this process is catalyzed by a membrane-associated NADPH oxidase (2), which transfers an electron to reduce molecular oxygen to superoxide. The enzyme system is inactive in resting cells but rapidly activates upon exposure of a phagocyte to a variety of particulate and soluble stimuli that act though several alternative pathways of transmembrane signal transduction (27). The exact structure of the oxidase remains unknown, but there is evidence to suggest that it is a transmembrane (4) electron transport system which includes a unique, low-midpoint-potential cytochrome $b$ (13) and probably an FAD-containing flavoprotein (24).

Most studies of the superoxide-generating system have utilized mature granulocytes, monocytes, and macrophages harvested from peripheral blood or peritoneal exudates. The induced differentiation of the HL-60 myeloid leukemia cell line provides a useful in vitro model of myeloid development $(11,29)$. The cell line, derived from a patient with acute myeloid leukemia, undergoes a low rate (1 to $5 \%$ of cells) of spontaneous myeloid differentiation in vitro (10). Incubation with polar solvents (such as dimethyl sulfoxide and $N, N$ dimethylformamide [DMF]), retinoic acid (RA), or a wide variety of other agents $(7,9,11)$ induces markedly increased differentiation to morphologic myelocytes, metamyelocytes, band forms, and polymorphonuclear leukocytes. Such differentiated HL-60 cells are capable of most granulocyte functions: chemotaxis, ingestion, respiratory burst activity, and bacterial killing $(12,18,29)$. Previous studies of superoxide generation in HL-60 cells have demonstrated the

\footnotetext{
* Corresponding author.

$\dagger$ Present address: Laboratory of Viral Oncology. The Rockefeller University, New York, NY 10021.
}

maturation of the NADPH oxidase, its cytochrome $b$ component, and the membrane potential response to cell activation $(29,30)$. However, examination of the molecular mechanisms of regulation of superoxide-generating activity has not been possible until the present time because no oxidaserelated probes have been available.

Recently, molecular cloning of the X-CGD gene and its cDNA has been accomplished (32), allowing identification of the gene defective in the X-linked form of chronic granulomatous disease, a disorder in which phagocytes lack NADPH oxidase activity $(5,14)$. The X-CGD gene product is the heavy chain of neutrophil cytochrome $b(15,36)$, which is a heterodimer $(31,33)$ composed of the 90 -kilodalton X-CGD-encoded glycoprotein and a 22-kilodalton nonglycosylated polypeptide (C. A. Parkos, M. C. Dinauer, L. E. Walker, R. A. Allen, A. J. Jesaitis, and S. H. Orkin, Proc. Natl. Acad. Sci. USA, in press).

The initial cloning of the X-CGD gene utilized and demonstrated the up-regulation of its expression in DMF-induced HL-60 cells. We have now further characterized the expression, inducibility, and control of the X-CGD gene during HL-60 granulocytic differentiation.

\section{MATERIALS AND METHODS}

Cell lines and culture conditions. HL-60 cells, originally obtained from Robert Gallo (National Cancer Institute, Bethesda, Md.), were passaged twice weekly in RPMI 1640 medium (GIBCO Laboratories) supplemented with $10 \%$ heat-inactivated fetal calf serum, $5.0 \mathrm{U}$ of penicillin per $\mathrm{ml}$, and $5 \mu \mathrm{g}$ of streptomycin per $\mathrm{ml}$ and maintained in a $7 \% \mathrm{CO}_{2}$ atmosphere at $37^{\circ} \mathrm{C}$.

The cells were seeded at $2.5 \times 10^{5} / \mathrm{ml}$, and inducers of differentiation were added $24 \mathrm{~h}$ later. Induction was initiated first by incubation with $10^{-6} \mathrm{M}$ RA for $24 \mathrm{~h}$, followed by the addition of $60 \mathrm{mM}$ DMF. We had previously established 
(K. A. Barker and P. E. Newburger, manuscript in preparation) that this regimen resulted in maximal granulocytic maturation of HL-60 cells.

Cell counts were performed in a hemacytometer, and viability was assessed by the ability of the cells to exclude $0.1 \%$ trypan blue dye. For morphological assessment of the cells, slides were prepared by centrifugation of the cells in a Shandon/Southern Cytospin centrifuge, stained with WrightGiemsa stain (Sigma Chemical Co.), and examined by phase microscopy under oil immersion at $\times 1,000$ magnification. Five stages of granulocytic differentiation were distinguished: promyelocytes, myelocytes, metamyelocytes, band cells, and polymorphonuclear leukocytes.

Isolation of peripheral blood granulocytes. Peripheral blood was collected in acid-citrate-dextrose, and granulocytes were purified by dextran and Ficoll-Hypaque sedimentation as described previously (3). Contaminating erythrocytes were removed by hypotonic lysis. The cells were washed and suspended in phosphate-buffered saline, pH 7.4 (PBS).

NBT reduction. Superoxide generation was determined by counting cells capable of reducing nitroblue tetrazolium (NBT) dye (29). Cells $\left(1.5 \times 10^{6}\right), 750 \mu$ l of PBS with $5 \mathrm{mM}$ glucose, $20 \mu \mathrm{l} 0.2 \% \mathrm{NBT}$, and $50 \mu \mathrm{l}$ of phorbol myristate acetate (PMA; $2 \mathrm{mg} / \mathrm{ml}$ ) in $1 \mathrm{mg}$ of bovine serum albumin per $\mathrm{ml}$ were incubated at $37^{\circ} \mathrm{C}$ for $20 \mathrm{~min}$. The reaction was stopped with ice-cold PBS. After a 10-s spin in a microfuge. the supernatant was removed, and the pellet was suspended in $10 \mu \mathrm{l}$ of serum, smeared gently on a slide, fixed in methanol, and stained with safranin. Two hundred cells were examined microscopically for the presence of blue granules. and cells with more than five blue granules were counted as NBT positive.

Elutriation of HL-60 cells. HL-60 cells were fractionated on the basis of buoyant density by centrifugal elutriation (22) in a Beckman JE-6B elutriator rotor. Cells $\left(5 \times 10^{8}\right)$ in $\log$ phase were pelleted and washed in sterile elutriation buffer (PBS with $1.5 \%$ heat-inactivated newborn calf serum, $5 \mathrm{U}$ of penicillin per $\mathrm{ml}$, and $5 \mu \mathrm{g}$ of streptomycin per $\mathrm{ml}$ ) at $4^{\circ} \mathrm{C}$. Then $70 \%$ ethanol, sterile water, and elutriation medium were pumped sequentially through the elutriation chamber before calibration of the flow rate with elutriation medium. For cell fractionation, the rotor speed was set at $2,800 \mathrm{rpm}$. The buffer flow rate was adjusted to $15 \mathrm{ml} / \mathrm{min}$, and the cells were injected into the rotor over a period of $2 \mathrm{~min}$. At this flow rate, all cells were retained in the rotor, and $150 \mathrm{ml}$ of buffer was collected to remove debris. After this initial wash, fractions were collected at increasing flow rates to collect increasingly larger cells. The flow rates for undifferentiated and 24-h RA-treated HL-60 cells were $35,38,42$, and $45 \mathrm{ml} /$ min. The final fraction of cells was obtained by maintaining the buffer flow rate at $45 \mathrm{ml} / \mathrm{min}$ and adjusting the rotor speed to 2,000 rpm. A prefraction was always collected after the load fraction, to be sure that differentiated cells would not be included in the analyzed fractions. Two-day differentiated HL-60 cells were loaded at a flow rate of $10 \mathrm{ml} / \mathrm{min}$ with the rotor speed at $2,800 \mathrm{rpm}$, and fractions were removed at $16,32,40,45 \mathrm{ml} / \mathrm{min}$; the final fraction was collected by maintaining the pump at the setting for $45 \mathrm{ml} /$ min and adjusting the rotor speed to $2,000 \mathrm{rpm}$.

The collected fractions were maintained on ice throughout the elutriation. After all fractions had been collected they were centrifuged, the pellets were washed in PBS, and the cells were counted. Differential stains and NBT assays were done on each fraction.

Determination of cell cycle stage by flow cytometry. The proportion of HL- 60 cells in the $G_{1}, S$, and $G_{2}-M$ phases of the cell cycle was determined by simultaneous flow cytometric measurement of cellular DNA content and the amount of bromodeoxyuridine incorporated into cellular DNA (16). HL-60 cells $\left(2 \times 10^{6}\right)$ were incubated with $10 \mu \mathrm{M}$ bromodeoxyuridine in RPMI medium with $10 \%$ fetal calf serum for $30 \mathrm{~min}$ in $7 \% \mathrm{CO}_{2}$ at $37^{\circ} \mathrm{C}$. The cells were washed twice with PBS, the pellet was suspended in $100 \mu$ l of normal saline, and $2 \mathrm{ml}$ of cold $70 \%$ ethanol was added with gentle vortexing. Cellular DNA was denatured by addition of $2 \mathrm{ml}$ of $4 \mathrm{~N} \mathrm{HCl}$, and the cells were neutralized with $0.1 \mathrm{M}$ $\mathrm{Na}_{2} \mathrm{~B}_{4} \mathrm{O}_{7}$. After centrifugation, $5 \mu \mathrm{l}$ of fluoresceinated antibromodeoxyuridine was added to the cells in $50 \mu \mathrm{l}$ of $0.5 \%$ Tween 20-PBS: after a 30-min incubation with the antibody, the cells were washed twice with the buffer. Propidium iodide at a final concentration of $20 \mu \mathrm{g} / \mathrm{ml}$ was added to stain total DNA, and the cells were analyzed on a FACS-440 fluorescence-activated cell sorter (Becton Dickinson), with a 488-nm excitation laser. Red fluorescence from propidium iodide was read with a 620-nm-band-path filter, and green fluorescence from fluorescein (anti-bromodeoxyuridine) was read with a 520-nm-band-path filter.

cDNA clones. The human X-CGD cDNA probe used for these studies is a 1.800-base-pair $B g$ lII restriction fragment, representing much of the $3^{\prime}$ untranslated region of the message (32). The 800-base-pair cDNA C16 (catalase probe) in PKY218 (8) was obtained from Gail Bruns (Harvard Medical School). The third exon of c-myc in pBR322. originally obtained from Kathleen Kelly, was provided by Susan Schiavi (University of Massachusetts Medical School). The human glutathione peroxidase probe is a fulllength cDNA identified by oligonucleotide screening of an HL-60 library (S. Chada and P. E. Newburger, J. Cell. Biochem. 12A(Suppl.):B306. 1988). The human transferrin receptor clone pTR-48, a partially characterized (8) 2-kilobase insert in puc9, was obtained from M. Greaves (Imperial Cancer Research Fund, London).

cDNA probes were labeled by nick translation as previously described (26).

Northern blot analysis of RNA. RNA was extracted by the guanidine hydrochloride method (20). Polyadenylated RNA was further purified from whole cell HL-60 RNA by passage over an oligo(dT)-cellulose column. For Northern (RNA) blotting (26), whole cell or polyadenylated RNA was denatured, electrophoresed in a $1.2 \%$ agarose-formaldehyde gel in morpholinepropanesulfonic acid buffer, and then transferred to a $0.45-\mu \mathrm{m}$-pore-size filter of Zeta Probe (BioRad Laboratories). Prehybridization, hybridization, filter washes, and filter stripping were performed as described previously (19). Filters were dried at room temperature before exposure to XAR film (Kodak) with Lightning-Plus intensifying screens (Kodak) at $-70^{\circ} \mathrm{C}$. Densitometry of the processed film was performed on a Quick-Scan R\&D densitometer (Helena Laboratories), and areas under the curves were determined by the weight of cut-out chart paper. Values for hybridization to control plasmid DNA were subtracted from those for the plasmid with specific probe.

Southern blot analysis of HL-60 DNA. High-molecularweight DNA was isolated as previously described (26) from cell nuclei (6) prepared from $10^{7}$ to $10^{8}$ cells. The DNA was digested with restriction enzymes according to the instructions of the distributor; electrophoresis, hydrolysis, and denaturation were performed by standard techniques (26). Transfer, prehybridization, and hybridization procedures were identical to those for Northern blots.

Nuclear runoff assay for transcription rates. Nuclear runoffs were performed with minor modifications of the method 
developed for HL-60 cells (25). HL-60 cells were harvested, washed once in cold PBS and once in reticulocyte standard buffer (10 mM Tris [pH 7.4], $10 \mathrm{mM} \mathrm{NaCl}, 3 \mathrm{mM} \mathrm{MgCl}$ ) and then lysed with $0.05 \%$ Nonidet P-40 in reticulocyte standard buffer on ice for $5 \mathrm{~min}$. The effectiveness of lysis was checked by phase microscopy. Nuclei were collected by centrifugation at $50 \times g$, washed twice in reticulocyte standard buffer, and suspended in nuclear freezing buffer (40\% glycerol, $50 \mathrm{mM}$ Tris [pH 8.3], $5 \mathrm{mM} \mathrm{MgCl}_{2}, 0.1 \mathrm{mM}$ EDTA) before immediate use or freezing at $-70^{\circ} \mathrm{C}$. At the time of the assay, the nuclear suspensions received additions of $20 \mu \mathrm{l}$ of $\left[\alpha^{32} \mathrm{P}\right] \mathrm{UTP}(3,000 \mathrm{Ci} / \mathrm{mmol} ; 10 \mu \mathrm{Ci} / \mu \mathrm{l})$ and $60 \mu \mathrm{l}$ of runoff buffer $\left(25 \mathrm{mM}\right.$ Tris [pH 8.0]; $12.5 \mathrm{mM} \mathrm{MgCl}_{2} ; 750$ $\mathrm{mM} \mathrm{KCl} ; 1.25 \mathrm{mM}$ each ATP, GTP, and CTP; $1 \mu \mathrm{M}$ UTP; $100 \mu \mathrm{g}$ of creatine phosphokinase; $5 \mathrm{mM}$ dithiothreitol; and $20 \mathrm{mM}$ phosphocreatine). After incubation for $30 \mathrm{~min}$ at $26^{\circ} \mathrm{C}$, the reaction was stopped by addition of $5 \mu$ l of DNase I ( $1 \mathrm{U} / \mu \mathrm{l})$ and $0.75 \mu \mathrm{l}$ of $2 \mathrm{M} \mathrm{CaCl}_{2}$, followed by incubation for $5 \mathrm{~min}$ at $26^{\circ} \mathrm{C}$.

Newly synthesized RNA was then extracted and detected as follows. To the above reaction mixture were added $10 \mu \mathrm{l}$ of proteinase $\mathrm{K}(10 \mathrm{mg} / \mathrm{ml})$ and $36 \mu l$ of $10 \times$ buffer containing $10 \%$ sodium dodecyl sulfate, $50 \mathrm{mM}$ EDTA, and $100 \mathrm{mM}$ Tris ( $\mathrm{pH} \mathrm{7.5);} \mathrm{then} \mathrm{the} \mathrm{sample} \mathrm{was} \mathrm{incubated} \mathrm{at} 37^{\circ} \mathrm{C}$ for 45 min. The sample was extracted with phenol-chloroform, and the nucleic acid was precipitated with ammonium acetate (final concentration, $2.3 \mathrm{M}$ ) and an equal volume of isopropanol on dry ice for $20 \mathrm{~min}$. After centrifugation, the pellet was suspended in water and precipitated with sodium acetate $(0.3 \mathrm{M})$ and 3 volumes of ethanol overnight at $-20^{\circ} \mathrm{C}$. After centrifugation, the pellet was suspended in hybridization buffer (see below), and the trichloroacetic acid-precipitable ${ }^{32} \mathrm{P}$ radioactivity was determined. Equal counts for each sample within an experiment, usually $3 \times 10^{6}$ to $8 \times 10^{6}$ $\mathrm{cpm}$, were then used for hybridizations as follows.

Specific sequences synthesized in the reaction were detected by hybridization to nonlabeled cDNA probe immobilized on filters. The cDNA was denatured by boiling for 10 min and then applied to Zeta-probe filters with sterile distilled water in a Schleicher \& Schuell slot-blot apparatus. Preliminary experiments established that the amounts of probe, 5 to $8 \mu \mathrm{g}$ per slot, were above the saturation point for complete binding of the runoff mRNA. Filters were baked for $2 \mathrm{~h}$ and prehybridized overnight at $65^{\circ} \mathrm{C}$ in $10 \mathrm{mM}$ Tris (pH 7.4), 0.4\% (wt/vol) polyvinylpyrrolidone, $0.4 \%$ (wt/vol) Ficoll $400,1 \mathrm{mg}$ of salmon sperm DNA per $\mathrm{ml}, 1 \%$ sodium pyrophosphate, and $0.2 \%$ sodium dodecyl sulfate. Filters were then hybridized with the labeled, newly synthesized, RNA for 36 to $48 \mathrm{~h}$ at $65^{\circ} \mathrm{C}$ in $10 \mathrm{mM}$ Tris (pH 7.4), $0.04 \%$ polyvinylpyrrolidone, $0.04 \%$ Ficoll $400,0.1 \mathrm{mg}$ of salmon sperm DNA per $\mathrm{ml}, 1 \%$ sodium pyrophosphate, and $0.2 \%$ sodium dodecyl sulfate. After hybridization, the filters were washed at $65^{\circ} \mathrm{C}$ for $1 \mathrm{~h}$, once with $1 \times \operatorname{SSC}(0.15 \mathrm{M} \mathrm{NaCl}$ plus $0.015 \mathrm{M}$ sodium citrate) $-0.1 \%$ sodium dodecyl sulfate and twice with $0.1 \times$ SSC $-0.1 \%$ sodium dodecyl sulfate, and then dried at room temperature and exposed to Kodak XAR film with an intensifying screen at $-70^{\circ} \mathrm{C}$ for various times. Hybridization signals on developed films were quantitated by visible light densitometry. The scans were cut out and weighed to derive the area under each density curve, and the data were corrected for nonspecific hybridization by subtraction of the value for the plasmid (pBR322) probe.

\section{RESULTS}

Initial studies of the tissue distribution of X-CGD gene expression (32) had shown transcripts to be present only in

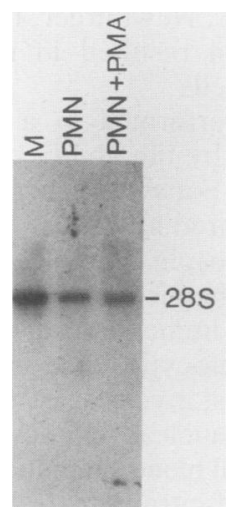

FIG. 1. X-CGD mRNA expression in peripheral blood mononuclear cells (M) (lane 1) and granulocytes (PMN) (lanes 2 and 3). The cells were isolated from human peripheral blood and granulocytes incubated for $20 \mathrm{~min}$ without (lane 2) or with (lane 3) PMA $(2 \mu \mathrm{g} / \mathrm{ml})$ before isolation of whole cell RNA and Northern blot analysis, performed as described in Materials and Methods.

cultured human monocyte-derived macrophages, the HL-60 cell line, and (at a much lower level) in transformed normal B-cell lines. Before studying the development of X-CGD gene expression in granulocytic HL-60 cells, we first examined mature human peripheral blood cells to demonstrate the presence of X-CGD mRNA in granulocytes. X-CGD gene transcripts were present in both fresh peripheral blood granulocytes and monocytes in a Northern blot (Fig. 1). Incubation of the granulocytes with PMA at concentrations that activate superoxide release did not result in increased levels of X-CGD message, indicating that PMA stimulation of oxidase activity is not regulated at the level of X-CGD mRNA abundance. The percentage of NBT-positive cells was $1 \%$ for the resting granulocytes and $99 \%$ for granulocytes stimulated by PMA.

DNA isolated from HL-60 cells was cut by several restriction endonucleases and examined on Southern blots for hybridization with a 0.3 -kilobase restriction fragment from the 3' untranslated region of X-CGD cDNA (32). In HL-60 DNA cut with PstI, EcoRI, or HindIII, only one band hybridized with the probe, suggesting that the X-CGD gene is present as a single copy in HL-60 cells (data not shown).

To define the inducibility of the X-CGD gene, HL-60 cells were treated with a sequential RA-DMF induction regimen for 5 days. During RA-DMF treatment, both DNA and RNA synthesis decreased almost to background levels (34). This treatment resulted in effective granulocytic differentiation, as shown by differential cell counts (Table 1). When RNA, extracted from HL-60 cells during 5 days of treatment with RA-DMF, was hybridized with labeled X-CGD probe, lowlevel hybridization was discernable on day 0 . The X-CGD signal doubled by day 1 and was increased 10 -fold by day 2 and 13-fold by day 4 of differentiation; hybridization remained high (8-fold above that at day 0 ) even at 5 days of differentiation (Fig. 2A). This rise in X-CGD mRNA accompanied an increase in oxidase activity, as measured by the ability of the cells to reduce NBT (Fig. 2B).

Because of the rapidity of induction of the X-CGD message, we examined the expression of the message during a shorter incubation with inducing agent. HL-60 cells were incubated with RA for $24 \mathrm{~h}$, RNA was extracted from the cells at intermediate time points, and Northern transfers were probed with X-CGD cDNA (Fig. 3A). X-CGD hybrid- 
TABLE 1. HL-60 cells incubated with RA-DMF treatment: differential counts“

\begin{tabular}{lrrrrr}
\hline \multirow{2}{*}{ Cell type } & \multicolumn{5}{c}{ \% of cells of indicated type on day: } \\
\cline { 2 - 6 } & 0 & 1 & 2 & 3 & 4 \\
\hline Promyelocyte & 96 & 83 & 43 & 19 & 2 \\
Myelocyte & 4 & 14 & 41 & 46 & 18 \\
Metamyelocyte & 0 & 3 & 15 & 30 & 42 \\
Band $^{b}$ & 0 & 0 & 1 & 5 & 34 \\
MN $^{b}$ & 0 & 0 & 0 & 0 & 4 \\
\hline
\end{tabular}

" HL-60 cells incubated for the indicated number of days with a sequential induction regimen of RA-DMF (see Materials and Methods) were harvested for differential cell counts on Wright-Giemsa-stained cytocentrifuge slides.

${ }^{h} \mathrm{PMN}$, polymorphonuclear leukocyte.

ization increased during $24 \mathrm{~h}$, rising almost twofold by $3 \mathrm{~h}$ and fivefold by $24 \mathrm{~h}$. This increase in the level of X-CGD transcripts correlated with the similarly early appearance of cells capable of superoxide generation, measured by NBT reduction (Fig. 3B).

To elucidate the mechanisms of regulation of the steadystate levels of X-CGD mRNA, nuclear runoff transcription assays were performed on cells before and at several times during differentiation. The autoradiograph from one such experiment (Fig. 4) demonstrates the rise in transcription of X-CGD during 3 days of differentiation with RA-DMF, compared with the probes pBR322 (plasmid control), glutathione peroxidase cDNA (which is down-regulated [S. Chada, C. Whitney, J. Wright, and P. E. Newburger, J. Cell. Biochem. 12A:B308, 1988]), and catalase (which varies little

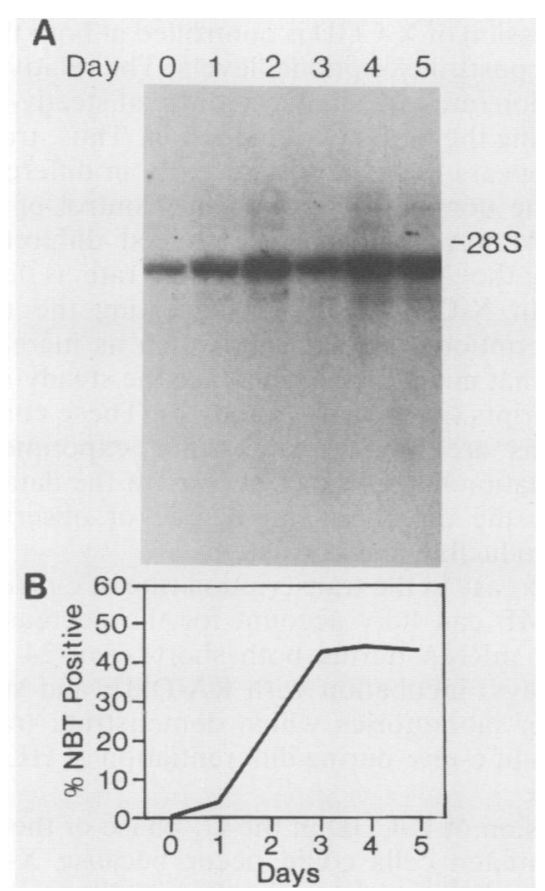

FIG. 2. (A) X-CGD mRNA expression in HL-60 cells induced to differentiate for 5 days with RA-DMF. Whole cell RNA was isolated from HL-60 cells harvested on the indicated days of differentiation, and Northern blot analysis with X-CGD cDNA was performed as described in Materials and Methods. (B) NBT reduction by HL-60 cells induced to differentiate for 5 days with RA-DMF. At the indicated days of differentiation, cells were examined for NBT reduction as described in Materials and Methods.

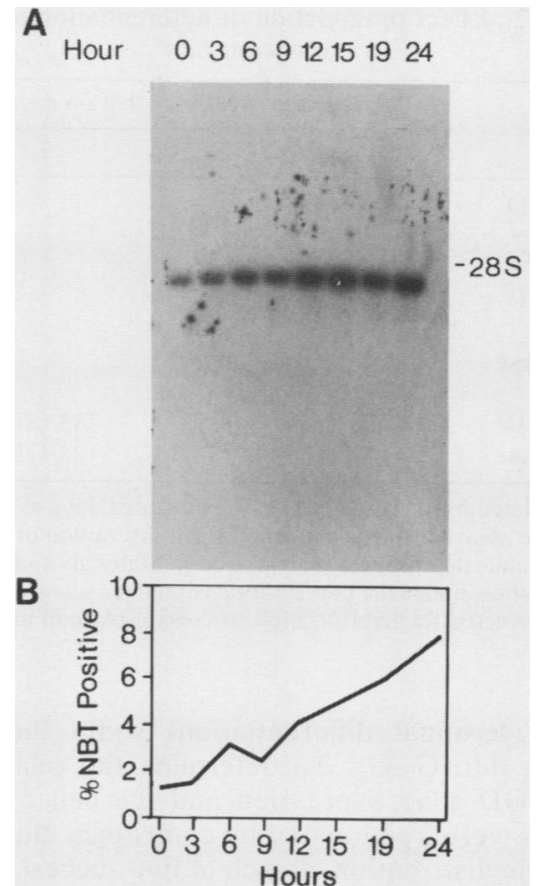

FIG. 3. (A) X-CGD mRNA expression in HL-60 cells induced to differentiate for $24 \mathrm{~h}$ with RA. Whole cell RNA was isolated from cells harvested at the indicated hours after RA addition and then analyzed by Northern blotting as described in Materials and Methods. (B) NBT reduction by HL-60 cells induced to differentiate for $24 \mathrm{~h}$ with RA. At the indicated hours of differentiation, cells were examined for NBT reduction as described in Materials and Methods.

in activity during HL-60 differentiation [35; Chada et al., J. Cell. Biochem. 12A:B308, 1988]). Table 2 shows the relative transcription rates of the $\mathrm{X}-\mathrm{CGD}$ gene, plus control probes for catalase and of c-myc (which rapidly decreases in expression upon induction of differentiation [21]). X-CGD transcription increased nearly 2 -fold after 1 or 2 days of induction, and 2.4- to 8-fold after 3 or 4 days. Concomitantly, the rate of transcription of c-myc decreased, as expected, to an undetectable level, and that of catalase decreased only slightly.

One interpretation of these data might be that the increase in X-CGD expression is due only to perturbation of the HL-60 cell cycle induced by RA-DMF, which (like any other

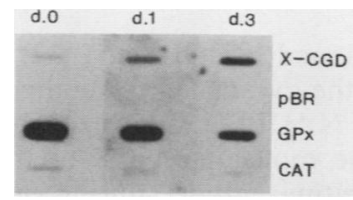

FIG. 4. Effect of differentiation on transcription rates of HL-60 cells, measured by nuclear runoff assay. The autoradiograph shows the amount of RNA transcribed in vitro by nuclei from cells induced to differentiate for the indicated number of days. The labels on the right indicate the gene products assayed: X-CGD; pBR322, plasmid control for nonspecific binding (pBR); glutathione peroxidase (GPx); and catalase (CAT). The filter was hybridized with total runoff RNA from equal numbers $\left(2 \times 10^{8}\right)$ of nuclei which were prepared from cells isolated on days (d) 0,1 , and 3 of induced differentiation and which incorporated $9 \times 10^{6}, 1.9 \times 10^{6}$, and $1.3 \times 10^{6} \mathrm{cpm}$ of [32P]uridine, respectively. 
TABLE 2. Effect of induction of differentiation on X-CGD transcription rate

\begin{tabular}{llrcccc}
\hline \multirow{2}{*}{ Expt } & \multirow{2}{*}{ Probe } & \multicolumn{4}{c}{ Transcription rate (\% of that on day 0) on day: } \\
\cline { 3 - 6 } & & \multicolumn{1}{c}{1} & \multicolumn{1}{c}{1} & 3 & 4 \\
\hline 1 & X-CGD & 7 & $13(186)$ & & $17(243)$ \\
& c-myc & 43 & $25(58)$ & & $0(0)$ \\
& & & & $30(176)$ & \\
2 & X-CGD & 17 & & $62(27)$ & \\
& c-myc & 230 & & $17(78)$ & \\
& Catalase & 25 & & & $383(814)$ \\
& & & & & \\
3 & X-CGD & 47 & $177(216)$ & & $23(72)$ \\
& Catalase & 32 & $54(169)$ & & \\
\hline
\end{tabular}

" Nuclei isolated from HL-60 cells at the indicated days of incubation with RA-DMF were assayed by nuclear runoff for transcription of mRNA hybridizing with the indicated probes, as described in Materials and Methods. Data represent the areas under the curves of densitometer scans of the hybridization filters, corrected for hybridization to control plasmid and expressed in arbitrary units.

inducer of terminal differentiation) shifts the cell cycle distribution into $G_{0}-G_{1}$. To determine the relationship between X-CGD gene expression and the cell cycle phases, HL-60 cells were fractionated by centrifugal elutriation, and the cell cycle distribution of each of five successive fractions was determined by flow cytometric analysis of bromodeoxyuridine uptake and DNA content (propidium iodide staining). RNA isolated from the cells of each fraction was probed with X-CGD cDNA (Fig. 5). In uninduced cells (Fig. 5A), X-CGD transcripts appeared primarily in the first fraction (enriched for $G_{1}-G_{0}$ ), probably representing gene expression in the subpopulation of cells undergoing spontaneous differentiation. After $24 \mathrm{~h}$ in RA (Fig. 5B), all cell fractions showed approximately equal X-CGD transcript levels. Reprobing of the same filter with a cDNA for the transferrin receptor showed the expected decrease in expression (17) in the first $\left(G_{1}-G_{0}\right)$ fraction (data not shown).

After $48 \mathrm{~h}$ in RA-DMF, differentiation had produced major morphological changes in the distribution of myeloid cell types, cell proliferation had greatly diminished, and superoxide-generating capacity had increased. With the centrifugal elutriation protocol utilized in these studies, 48-h differentiated cells fractionate less by stage of the cell cycle than by degree of differentiation, with the more mature cells eluting in the earlier fractions (30). X-CGD was expressed strongly in all fractions but the last, which contained the few remaining undifferentiating and mitotic cells (Fig. 5C).

\section{DISCUSSION}

The recently cloned X-CGD gene (32) encodes one polypeptide chain of the cytochrome $b$ component of the superoxide-generating NADPH oxidase of phagocytic cells (15, 35). To study the molecular basis of the development of superoxide-generating activity during myeloid maturation, we examined the expression, inducibility, and control of the $\mathrm{X}$-CGD gene during induced granulocytic differentiation of the HL-60 human myeloid cell line.

The level of X-CGD transcripts increased during differentiation and paralleled the increase in the numbers of cells exhibiting respiratory burst activity (measured as NBT reduction). These results confirm and extend our previous data obtained in the course of the cloning of the X-CGD gene (32).

Two interesting aspects of the rise in steady-state X-CGD transcript levels were the rapidity of induction of the X-CGD

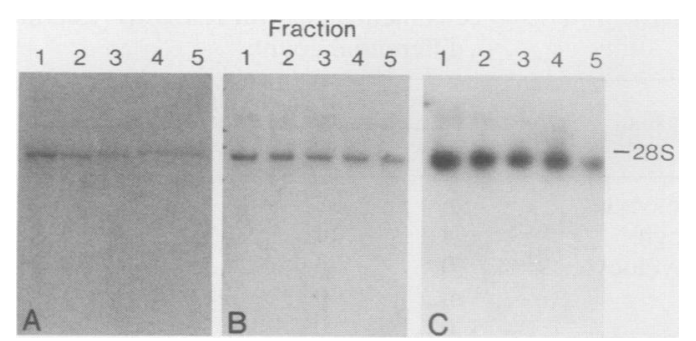

FIG. 5. X-CGD mRNA expression in HL-60 cells fractionated by centrifugal elutriation. The fractions are numbered in order of elution and represent enriched populations of $G_{1}-G_{0}$ cells in fraction 1 and $G_{2}-M$ in fraction 5 , with $S$-phase cells in intermediate fractions. (A) Uninduced HL-60 cells. (B) HL-60 cells induced to differentiate for $24 \mathrm{~h}$ with $10^{-6} \mathrm{M}$ RA. (C) HL-60 cells treated with RA-DMF for 2 days. Fractions 1, 2, and 3 contained NBT-positive cells (i.e., capable of PMA-stimulated superoxide generation); fractions 4 and 5 contained NBT-negative cells.

mRNA and the maintenance of high levels of X-CGD mRNA late in the course of RA-DMF-induced differentiation, when RNA synthesis is almost at background levels. The former observation helps to explain the previous finding that the increase in NBT-positive cells occurs even before any detectable morphologic change in the induced HL-60 population (29). The latter observation, together with the detection of X-CGD mRNA transcripts in fully mature peripheral blood granulocytes, suggests that mature cells may maintain some ongoing synthesis of the NADPH oxidase, rather than stockpiling the necessary supply during the process of differentiation.

The studies of transcription rates by nuclear runoff suggest that expression of X-CGD is controlled at both the transcriptional and posttranscriptional levels. The relative changes in transcription rates are similar to those of steady-state mRNA levels during the first day of induction. Thus, transcriptional control appears to be important early in differentiation and may be the dominant factor in the control of steady-state mRNA. At days 3 and 4 of induced differentiation, the change in the X-CGD transcription rate is less than the increase in X-CGD mRNA, suggesting the operation of posttranscriptional mechanisms, such as increased mRNA stability, that might further increase the steady-state level of the transcripts (particularly at day 4). These comparisons of proportions are approximate, since experiment-to-experiment variation makes exact overlap of the data impossible. However, the direction and degree of observed changes were reproducible and consistent.

The decrease in the transcription rate of $c-m y c$ in response to RA-DMF can fully account for the decrease in steadystate myc mRNA during both short-term $(24 \mathrm{~h})$ and longterm ( 5 days) incubation with RA-DMF and supports data from other laboratories which demonstrate transcriptional regulation of c-myc during differentiation of HL- 60 cells ( 23 , 37).

Expression of X-CGD in the $G_{1}$ phase of the cell cycle in undifferentiated cells could occur because $X$-CGD is cell cycle controlled and hence preferentially expressed in $G_{1}$. Alternatively, the finding could represent expression of the gene in the small number of cells spontaneously committed to differentiate and blocked in $G_{1}-G_{0}$. Twenty-four hours after HL-60 cells are induced to differentiate with RA, the $\mathrm{X}$-CGD mRNA is expressed equally strongly in every phase of the cycle, indicating that the cell need not be in $G_{1}-G_{0}$, or be morphologically and functionally mature, to express the 
X-CGD mRNA. The results of the experiment with HL-60 cells incubated for 2 days with RA-DMF before separation into immature and mature fractions indicate that cells which are induced but still morphologically undifferentiated express X-CGD mRNA as strongly as those already showing morphologic change. Only fraction 5 cells, the most undifferentiated, have lower levels of X-CGD mRNA. Thus, the expression of X-CGD mRNA during granulocytic differentiation appears to be independent of the cell cycle and to occur in both proliferating and nonproliferating, and both morphologically mature and immature cells.

\section{ACKNOWLEDGMENTS}

We thank Marcia McFadden for operation of the fluorescenceactivated cell sorter and Mark Groudine for advice on the nuclear runoff assay.

This work was supported in part by the Socha Memorial Fund for Chronic Granulomatous Disease Research and by Public Health Service grant CA-38325 from the National Institutes of Health. S.H.O. is an Investigator of the Howard Hughes Medical Institute. P.E.N. is an Established Investigator of the American Heart Association.

\section{LITERATURE CITED}

1. Babior, B. M. 1984. Oxidants from phagocytes: agents of defense and destruction. Blood 64:959-966.

2. Babior, B. M. 1987 . The respiratory burst oxidase. Trends Biochem. Sci. 12:241-245.

3. Babior, B. M., and H. J. Cohen. 1981. Leukocyte function. Churchill Livingstone, New York.

4. Babior, G. L., R. E. Rosin, B. J. McMurrich, W. A. Peters, and B. M. Babior. 1981. Arrangement of the respiratory burst oxidase in the plasma membrane of the neutrophil. J. Clin. Invest. 67:1724-1728.

5. Baehner, R. L., and D. G. Nathan. 1967. Leukocyte oxidase: defective activity in chronic granulomatous disease. Science 155:835-836.

6. Bell, G. I., J. H. Karam, and W. J. Rutter. 1981. Polymorphic DNA region adjacent to the $5^{\prime}$ end of the human insulin gene. Proc. Natl. Acad. Sci. USA 78:5759-5763.

7. Breitman, T. R., S. J. Collins, and B. R. Keene. 1981. Terminal differentiation of human promyelocytic leukemic cells in primary culture in response to retinoic acid. Blood 57:1000-1004.

8. Bruns, G. A. P., T. Glaser, J. F. Gusella, D. Housman, and S. H. Orkin. 1984. Chromosome 11 probes identified with a catalase oligonucleotide. Am. J. Hum. Genet. 36:25S.

9. Collins, S. J., A. Bodner, R. Ting, and R. C. Gallo. 1980. Induction of morphological and functional differentiation of human promyelocytic leukemia cells (HL-60) by compounds which induce differentiation of murine leukemia cells. Int. J. Cancer 25:213-218.

10. Collins, S. J., R. C. Gallo, and R. E. Gallagher. 1977. Continuous growth and differentiation of human myeloid leukaemic cells in suspension culture. Nature (London) 270:347-349.

11. Collins, S. J., F. W. Ruscetti, R. E. Gallagher, and R. C. Gallo. 1978. Terminal differentiation of human promyelocytic leukemia cells induced by dimethyl sulfoxide and other polar solvents. Proc. Natl. Acad. Sci. USA 75:2458-2462.

12. Collins, S. J., F. W. Ruscetti, R. E. Gallagher, and R. C. Gallo. 1979. Normal functional characteristics of cultured human promyelocytic leukemia cells (HL-60) after induction of differentiation by dimethylsulfoxide. J. Exp. Med. 149:969-974.

13. Cross, A. R., F. K. Higson, O. T. G. Jones, A. M. Harper, and A. W. Segal. 1982. The enzymic reduction and kinetics of oxidation of cytochrome b of neutrophils. Biochem. J. 204:479485 .

14. Curnutte, J. T., D. M. Whitten, and B. M. Babior. 1974. Defective superoxide production by granulocytes from patients with chronic granulomatous disease. N. Engl. J. Med. 290:593-
597.

15. Dinauer, M. C., S. H. Orkin, R. Brown, A. J. Jesaitis, and C. A. Parkos. 1987. The glycoprotein encoded by the X-linked chronic granulomatous disease locus is a component of the neutrophil cytochrome b complex. Nature (London) 327:717-720.

16. Dobeare, F., H. Gratzner, M. G. Pallavicini, and J. W. Gray. 1983. Flow cytometric measurement of total DNA content and incorporated bromodeoxyuridine. Proc. Natl. Acad. Sci. USA 80:5573-5577.

17. Felsted, R. L., S. K. Gupta, C. J. Glover, S. A. Fischoff, and R. E. Gallagher. 1983. Cell surface membrane protein changes during the differentiation of cultured human promyelocytic leukemic HL-60 cells. Cancer Res. 43:2754-2761.

18. Fontana, J. A., D. G. Wright, E. Schiffman, B. A. Corcoran, and A. B. Deisseroth. 1980. Development of chemotactic responsiveness in myeloid precursor cells: studies with a human leukemia cell line. Proc. Natl. Acad. Sci. USA 77:3664-3668.

19. Gatti, R. A., P. Concannon, and W. Salser. 1984. Multiple use of Southern blots. Biotechniques 2:148-155.

20. Ginsburg, D., R. I. Handin, D. T. Bonthron, T. A. Donlon, G. A. P. Bruns, S. A. Latt, and S. H. Orkin. 1985. Human von Willebrand factor: isolation of complementary DNA clones and chromosomal location. Science 228:1401-1406.

21. Grosso, L. E., and H. C. Pitot. 1985. Transcriptional regulation of c-myc during chemically induced differentiation of HL-60 cultures. Cancer Res. 45:847-850.

22. Heil, M. F., J. M. Wu, and J. W. Chiao. 1985. Cell-cycle differences of HL-60 leukemia cells fractionated by centrifugal elutriation. Biochim. Biophys. Acta 845:17-20.

23. High, K. A., C. A. Stolle, J. W. Schneider, W. Hu, and E. J. Benz, Jr. 1987. c-myc gene inactivation during induced maturation of HL-60 cells. Transcriptional repression and loss of a specific DNAse 1 hypersensitive site. J. Clin. Invest. 79:93-99.

24. Light, D. R., C. Walsh, A. M. O'Callaghan, E. J. Goetzl, and A. I. Tauber. 1981. Characteristics of the cofactor requirements for the superoxide-generating NADPH oxidase of human polymorphonuclear leukocytes. Biochemistry 20:1468-1476.

25. Linial, M., N. Gunderson, and M. Groudine. 1985. Enhanced transcription of c-myc in bursal lymphoma cells requires continuous protein synthesis. Science 230:1126-1132.

26. Maniatis, T., E. F. Fritsch, and J. Sambrook. 1982. Molecular cloning: a laboratory manual. Cold Spring Harbor Laboratory, Cold Spring Harbor, N.Y.

27. McPhail, L. C., C. C. Clayton, and R. Snyderman. 1984. The NADPH oxidase of human polymorphonuclear leukocytes. Evidence for regulation by multiple signals. J. Biol. Chem. 259: 5768-5775.

28. Nathan, C. F., and S. Tsunawaki. 1986. Biochemistry of macrophages. CIBA Found. Symp. 118:211-230.

29. Newburger, P. E., M. E. Chovaniec, J. S. Greenberger, and H. J. Cohen. 1979. Functional changes in human leukemic cell line HL-60: a model for myeloid differentiation. J. Cell Biol. 82:315322.

30. Newburger, P. E., C. Speier, N. Borregaard, C. E. Walsh, J. C. Whitin, and E. R. Simons. 1984. Development of the superoxide-generating system during differentiation of the HL-60 promyelocytic leukemia cell line. J. Biol. Chem. 259:3771-3776.

31. Parkos, C. A., R. A. Allen, C. G. Cochrane, and A. J. Jesaitis. 1987. Purified cytochrome b from human granulocyte plasma membrane is comprised of two polypeptides of 91,000 and 22.000 relative molecular weights. J. Clin. Invest. 80:732-742.

32. Royer-Pokora, B., L. M. Kunkel, A. P. Monaco, S. C. Goff, P. E. Newburger, R. L. Baehner, F. S. Cole, J. T. Curnutte, and S. H. Orkin. 1986. Cloning the gene for an inherited disorderchronic granulomatous disease-on the basis of its chromosomal location. Nature (London) 322:32-38.

33. Segal, A. W. 1987. Absence of both cytochrome b-245 subunits from neutrophils in X-linked chronic granulomatous disease. Nature (London) 326:88-91.

34. Seger, R. A., L. Tiefenauer, T. Matsunaga, A. Wildfeuer, and P. E. Newburger. 1983. Chronic granulomatous disease due to granulocytes with abnormal NADPH oxidase activity and deficient cytochrome b. Blood 61:423-428. 
35. Speier, C., and P. E. Newburger. 1986. Changes in superoxide dismutase, catalase, and the glutathione cycle during induced myeloid differentiation. Arch. Biochem. Biophys. 251:551-557.

36. Teahan, C., P. Rowe, P. Parker, N. Totty, and A. W. Segal. 1987. The X-linked chronic granulomatous disease gene codes for the beta-chain of cytochrome b-245. Nature (London) 237:
$720-721$.

37. Westin, E. H., F. Wong-Staal, E. P. Gelmann, R. D. Favera, T. S. Papas, J. A. Lautenberger, A. Eva, E. P. Reddy, S. R. Tronick, S. A. Aaronson, and R. C. Gallo. 1982. Expression of cellular homologues of retroviral onc genes in human hematopoietic cells. Proc. Natl. Acad. Sci. USA 79:2490-2494. 